\title{
Labyrinthe
}

2| 1999

Numéro 2

\section{Penser en images : de l'usage des hiéroglyphes au cinéma}

Traduit de l'américain par Marc Chénetier

Vachel Lindsay

\section{(2) OpenEdition \\ Journals}

Electronic version

URL: http://journals.openedition.org/labyrinthe/366

DOI: $10.4000 /$ labyrinthe.366

ISSN: 1950-6031

\section{Publisher}

Hermann

Printed version

Date of publication: 15 January 1999

Number of pages: 100-109

\section{Electronic reference}

Vachel Lindsay, «Penser en images : de l'usage des hiéroglyphes au cinéma », Labyrinthe [Online],

2 | 1999, Online since 04 March 2005, connection on 20 April 2019. URL : http://

journals.openedition.org/labyrinthe/366 ; DOI : 10.4000/labyrinthe.366

This text was automatically generated on 20 April 2019.

Propriété intellectuelle 
Penser en images : de l'usage des hiéroglyphes au cinéma

Traduit de l'américain par Marc Chénetier

Vachel Lindsay 